Survai potensi, distribusi sumber daya, dan usaha ikan hias air tawar ..... (Rudhy Gustiano)

\title{
SURVAI POTENSI, DISTRIBUSI SUMBER DAYA, DAN USAHA IKAN HIAS AIR TAWAR DI BEBERAPA SENTRA PRODUKSI
}

\author{
Rudhy Gustiano*), Tri Heru Prihadi**, dan Eni Kusrini* ${ }^{* *}$ \\ *) Balai Riset Perikanan Budidaya Air Tawar, Bogor \\ *) Pusat Riset Perikanan Budidaya
}

\begin{abstract}
ABSTRAK
Budidaya ikan hias di Indonesia sampai saat ini masih mengalami kendala baik dalam hal pemeliharaan maupun pemasarannya. Berkaitan dengan hal tersebut, perlu adanya evaluasi secara berkesinambungan dan pemecahan masalahmasalah yang ada. Dengan demikian komoditas ikan hias dapat lebih ikut berperan dalam pemulihan perekonomian nasional. Dalam rangka mendukung langkah-langkah pencapaian sasaran tersebut sangat diperlukan riset yang mendukung untuk potensi, distribusi sampai dengan sentra produksi di berbagai provinsi di Indonesia. Berdasarkan survai yang dilakukan, kegiatan budidaya ikan hias masih terkonsentrasi di kota-kota besar dan didominasi tangkapan dari alam.
\end{abstract} KATA KUNCl: ikan hias, sentra produksi,
komoditas

\section{PENDAHULUAN}

Sehubungan dengan peranan ikan hias dalam aktivitas perdagangan, sangat diperlukan pemahaman yang berkaitan dengan pengembangan komoditas tersebut (Gustiano et al., 2005). Ikan hias digandrungi penggemarnya bukan hanya karena keindahannya juga karena kepercayaan akan membawa keberuntungan. Harga menjadi relatif untuk komoditas ikan hias, tergantung "trend" yang dapat berubah dari waktu kewaktu meskipun ada komoditas yang sudah stabil seperti koki, koi, guppy, cupang, dan lain-lain.

Secara umum usaha ikan hias meliputi pemanfaatan sumber daya penangkapan dan budidaya. Walaupun sumber daya perikanan dapat pulih dan diperbarui, tetapi perlu pengelolaan agar dapat lestari. Demikian juga daya kompetitif ikan hias yang mengandalkan sumber daya alam harus dikurangi. Kegiatan penangkapan sepenuhnya tergantung pada keadaan alam, maka hasilnya pun tidak dapat diramalkan, sehingga produksinya pun tidak dapat ditentukan (Dwiponggo, 1993). Kondisi tersebut mengakibatkan pemenuhan permintaan akan suatu jenis dalam jumlah tertentu sukar dipenuhi. Terlebih lagi dengan adanya keinginan dari negara-negara importir yang berkaitan dengan cara eksploitasi sumber daya alam yang lebih memperhatikan aspek-aspek kelestarian dan konservasi. Oleh karena itu, peranan budidaya di masa mendatang akan lebih besar.

Saat ini, masalah umum yang ada pada dunia ikan hias adalah belum mampunya memenuhi permintaan pasar yang cukup besar baik dari kuantitas maupun kualitas dan kesinambungan pengadaan produk serta rantai pemasaran yang efisien (Satyani, 2003). Dibandingkan dengan ikan konsumsi, peranan pemerintah dalam pengembangan usaha budidaya ikan hias masih terbatas. Namun patut disyukuri telah ada pembenahan melalui pembentukan forum komunikasi yang mendiskusikan masalah-masalah yang berkaitan dengan dunia ikan hias dan komisi nasional ikan hias. Di awal tahun 2004, Indonesia untuk pertama kali memiliki terminal agrobisnis (holding ground) ikan hias. Tujuan didirikan terminal atau raiser tersebut antara lain untuk meningkatkan nilai tambah dan daya saing ikan hias, menciptakan peningkatan transaksi dan peningkatan pendapatan pengusaha ikan hias, mewujudkan jaringan pemasaran di pasar dalam negeri dan luar negeri, serta menciptakan manajemen pengelolaan yang profesional.

Berkaitan dengan beberapa kendala yang ada pada usaha ikan hias, perlu dilakukan evaluasi yang terusmenerus dan antisipasi dini untuk memecahkan masalahmasalah yang ada. Menurut Sukadi (2003), bahwa pengembangan ikan hias di Indonesia harus dapat mendayagunakan potensi sumber daya lahan, air, maupun sumber daya ikan hiasnya sendiri, meningkatkan devisa negara, mendorong menghidupkan kegiatan produksi berbasis ekonomi rakyat, serta mempercepat pembangunan pedesaan. Survai ini bertujuan untuk mendapatkan dan mengolah data, informasi pemanfaatan, pengelolaan, dan pelestarian ikan hias air tawar untuk penyusunan kebijakan, peta potensi sumber daya dan usaha ikan hias. 


\section{LOKASI SURVAI}

Survai data yang dikumpulkan dan digunakan dalam kegiatan studi ini yaitu data primer dan data sekunder dari Provinsi: Sumatera Utara, Jambi, Sumatera Selatan, Jawa Timur, Bali, dan Kalimantan Barat. Data primer merupakan data yang dikumpulkan di lapangan terutama data yang berhubungan dengan potensi dan pengelolaan sumber daya ikan hias, produksi ikan hias, usaha penangkapan, dan budidaya ikan hias. Pemasaran yang dipelajari baik secara langsung maupun pemasaran yang dilakukan melalui rantai pemasaran yang telah ada. Pengumpulan akan dilakukan dengan menggunakan metode Participatory Rapid Appraisal (PRA) dan survai (menggunakan panduan daftar topik pertanyaan yang kemudian dikumpulkan dengan cara wawancara langsung dan mendalam dengan responden). Data sekunder berupa informasi yang berhubungan dengan hasil studi atau pustaka yang berhubungan dengan pemanfaatan, pengelolaan, dan pemasaran ikan hias, termasuk kebijakan yang berhubungan dengan pemanfaatan dan pengelolaan ikan hias air tawar.

\section{Provinsi Sumatera Utara}

Kegiatan budidaya ikan hias di Sumatera Utara ada yang sudah merupakan mata pencaharian utama pembudidaya ikan, tetapi lebih banyak sebagai mata pencaharian sampingan. Pembudidaya ikan yang mata pencaharian utamanya dari budidaya ikan membudidayakan ikan hias skala besar. Budidaya ikan hias hasil introduksi merupakan yang paling maju di Medan. Jenis ikan yang dibudidayakan secara massal dengan manajemen pemasaran yang sudah baik adalah jenis discus. Sebagian besar pedagang merangkap sebagai pembudidaya dan penampung, ikan yang dipasarkan/dijual merupakan hasil dari budidaya baik budidaya yang dilakukan sendiri maupun yang dikumpulkan dari pembudidaya kecil yang terdapat di Medan. Secara umum, sebagian besar ikanikan budidaya ini merupakan ikan-ikan hasil introduksi. Sedangkan sebagian lagi merupakan hasil tangkapan di perairan umum oleh nelayan-nelayan di Rantau Prapat, Langsa Provinsi Aceh dan Sibolga. Ada sembilan jenis ikan air tawar yang sudah diekspor. Menurut Girsang et al. (1994), terdapat 34 jenis ikan hias hasil introduksi/impor yang berhasil diinventarisasi di Sumatera Utara.

\section{Provinsi Jambi}

Provinsi Jambi dengan Sungai Batangharinya merupakan penghasil ikan hias yang utama. Di antara jenis ikan yang ada, botia merupakan komoditas utama. Ikan hias yang ada di daerah al iran Sungai Batanghari tercatat lebih dari 40 jenis. Beberapa di antaranya mempunyai nilai ekonomis penting antara lain: baung, jilin, selusur batang, tilan merah, botia, puting beliung, dan caka caka. Potensi produksi ikan hias di Jambi diperkirakan sebesar 5.600.000 ekor/tahun dan tingkat pemanfaatan sumber daya ikan hias di provinsi ini telah mencapai $62,5 \%$ dari potensi lestarinya dan masih didominasi oleh ikan botia. Pada tahun 1978 produksi ikan botia di daerah Jambi sekitar 11 juta ekor dan meningkat menjadi 12 juta ekor pada tahun 1983, namun pada tahun 1987 produksinya menurun 1,5 juta ekor. Kondisi tersebut mencerminkan bahwa populasi ikan hias botia di alam Provinsi Jambi cenderung menurun sehingga terancam kelestariannya. Oleh karena itu, diperlukan suatu tindakan atau upaya penyelamatan dan pengelolaannya.

\section{Provinsi Sumatera Selatan}

Sumatera Selatan menghasilkan 29.160 ton ikan hias air tawar. Ikan hias tersebut, berasal dari daerah aliran Sungai Musi. Jenis-jenis yang paling banyak diusahakan adalah cupang, discus, baung, dan arwana.

\section{Provinsi Jawa Timur}

Untuk daerah Jawa Timur, salah satu daerah pemasok terbesar ikan hias air tawar hasil budidaya adalah Kabupaten Tulung Agung (Sastrawidjaja, 2003). Terutama dari jenis ikan mas koki (Carrasius auratus), perkembangannya sangat baik karena mempunyai prospek yang cerah ditinjau dari segi pasar. Ikan hias mas koki dikenal masyarakat pembudidaya ikan di Tulung Agung sejak tahun 1978. Mulai tahun 1983 teknologi pembudidayaan ikan hias diterima oleh masyarakat sebagai bagian sumber mata pencaharian dan tahun 2000 telah berkembang di sembilan kecamatan. Sedangkan untuk daerah Blitar didominasi oleh jenis koi (Satyani, kompri).

Usaha ikan hias di Tulung Agung sampai sekarang telah berkembang dan mencapai 2.150 rumah tangga dan pada tahun 1999 telah mencapai nilai jual Rp 11 milyar (Kadinas Tulung Agung, kompri). Pembudidaya ikan hias ini juga telah mampu menciptakan lapangan pekerjaan dan tambahan penghasilan bagi masyarakat. Hasil pembudidayaan ikan hias dari pembudidaya dijual keluar daerah melalui pedagang pembeli yang datang dari luar Tulung Agung, dan selanjutnya dipasarkan ke berbagai daerah (khususnya kota-kota besar), sedangkan pembudidaya ikan hias Tulung Agung hanya membudidayakan dan belum secara langsung ikut memasarkan hasil produksi budidayanya sendiri. Produksi ikan hias dipasarkan melalui tiga cara: pertama, pembeli membeli ikan di kolam pembudidaya dengan syarat pembayaran tunai atau kredit dan transportasi menjadi tanggungan pembeli; kedua, pembudidaya ikan hias melakukan pemasaran melalui 
kerja sama dengan PIHI (Anonim, 2005); ketiga melalui pedagang perantara.

\section{Provinsi Bali}

Anggraeni et al. (1994) melaporkan bahwa jenis ikan hias air tawar yang diperdagangkan di Bali pada tahun 1993 ada 29 jenis. Usaha budidaya ikan hias air tawar dirintis di Kabupaten Badung. Dilaporkan juga bahwa komoditas ikan hias air tawar di Bali kurang berkembang dan didominasi oleh jenis-jenis yang sudah umum/ konvensional. Pembudidaya ikan air tawar lainnya lebih mengutamakan jenis-jenis ikan konsumsi karena permintaan akan ikan-ikan konsumsi di Provinsi Bali yang merupakan daerah tujuan wisata cukup besar dan kebutuhan akan ikan-ikan konsumsi inipun sebagian masih didatangkan dari luar.

Minat masyarakat yang masih kurang dalam memelihara ikan hias air tawar menyebabkan komoditas ikan air tawar belum terlalu berkembang. Oleh karena itu, sebagian besar ikan hias air tawar yang dipasarkan didatangkan dari daerah Jawa Timur. Sedikitnya jumlah pedagang ikan hias air tawar di daerah ini menggambarkan kurangnya permintaaan akan ikan hias air tawar. Kendala yang dihadapi oleh para pedagang adalah tingginya tingkat kematian ikan akibat transportasi yang kurang baik dan serangan penyakit menyebabkan naiknya harga jual ikan. Hal tersebut terjadi karena kurangnya pasok ikan dari daerah yang dekat dengan lokasi penjualan akibat kurangnya pembudidaya di daerah ini. Diharapkan dengan adanya pasok ikan dari pembudidaya yang dekat dengan lokasi penjualan akan menekan kematian dan harga jual ikan.

Sedangkan hasil survai yang dilakukan di Provinsi Bali pada tahun 2005 memperlihatkan daerah pengembangan usaha budidaya ikan hias air tawar di Bali ada di empat kabupaten/kota yaitu Denpasar, Badung, Tabanan, dan Buleleng. Lahan yang digunakan untuk usaha budidaya adalah kolam, sawah, dan lahan pekarangan. Ada 8 kelompok petani yang telah mengembangkan usaha budidaya yang terdiri atas 208 rumah tangga. Di Denpasar ada 1 kelompok dengan jumlah anggota 29 orang, jenis ikan yang dikembangkan adalah koki Bali. Di Kabupaten Badung ada 4 kelompok dengan jumlah anggota 108 tersebar di 4 kecamatan yaitu Abiansemal, Petang, Mengwi, dan Kuta Utara, dengan jenis ikan yang dikembangkan komet, koi, tetra, mantis, dan cyklid. Di Kabupaten Tabanan terdapat 3 kelompok dengan jumlah anggota 51 orang tersebar di 3 kecamatan, yaitu Kecamatan Kediri, Selemadeg, dan Penebel, dengan jenis yang dikembangkan adalah komet, plati, dan cichlid.
Sedangkan di Kabupaten Buleleng sebanyak 30 orang tersebar di 6 kecamatan, dan jenis ikan yang dikembangkan plati, koi, komet, dan sebagian jenis tetra. Semuanya bergabung dalam Himpunan Petani Ikan Hias Air Tawar (HIPIKAT) Bali.

Secara keseluruhan jenis ikan hias yang dipelihara sekitar 90 jenis, namun yang sudah berhasil dikembangbiakkan sebanyak 72 jenis seperti koi, komet, plati, tetra, cichlid, mantis, dan lain lain. Rata-rata produksi ikan hias air tawar yang dihasilkan mencapai 137.500 ekor setiap bulannya, kebanyakan dari jenis plati, tetra, cichlid, dan koki.

\section{Provinsi Kalimantan Barat}

Kegiatan budidaya ikan hias air tawar di Kalimantan Barat dilakukan pada tahun 1980, jenis ikan hias yang diusahakan adalah ikan hias yang mempunyai nilai ekspor tinggi (arwana dan botia). Perusahaan penangkaran arwana di Kalimantan Barat berjumlah 18. Hasil wawancara yang dilakukan di Pontianak mengatakan bahwa ikan arwana dipijahkan secara massal dalam satu petak kolam berukuran $400--500 \mathrm{~m}^{2}$, dengan jumlah induk berkisar antara 200--300 ekor. Produksi hasil pemijahan per kolam berkisar antara 100--150 ekor dengan waktu pemanenan berkisar antara 2--3 bulan. Selanjutnya pemeliharaan benih dilakukan di dalam akuarium dengan kepadatan 20--25 ekor selama 1--2 bulan dengan target ukuran 10--15 cm untuk ekspor. Dalam pemeliharaan arwana, pakan yang diberikan berupa ikan rucah, kepiting, udang, dan pelet buatan.

Sedangkan untuk ikan botia masih dalam tahap penangkaran, hasil yang diperoleh merupakan hasil tampungan dari penangkapan di alam. Para penampung umumnya memiliki 20--25 nelayan binaan. Sumber botia di alam berasal dari hulu Sungai Kapuas. Musim ikan botia pada umumnya pada bulan Oktober sampai Januari. Penangkapan dilakukan menggunakan bubu yang terbuat dari bambu. Jenis ikan hias lokal lainnya yang perlu mendapat perhatian untuk dikembangkan karena potensi pasar dan mempunyai nilai tinggi adalah rasbora, gobilis, ringgu, gastromyzon, black line, rasbora red line, dan tiger fish (Tabel 1). Dari Tabel 1, untuk 8 jenis ikan hias lokal yang paling menonjol terlihat bahwa ekspor ikan hias lokal mempunyai prospek yang cukup bagus. Sedangkan untuk jenis primadona penurunan yang terjadi pada tahun 2004 perlu mendapat perhatian serius untuk mengantisipasi penurunan populasi di alam akibat penangkapan yang berlebih.

Volume ekspor ikan hias dari Kalimantan Barat sejak tahun 2003 mengalami kenaikan yang signifikan 35,76\% 
Tabel 1. Jenis ikan hias potensial di Kalimantan Barat

\begin{tabular}{lrr}
\hline \multicolumn{1}{c}{ Jenis ikan } & Tahun $\mathbf{2 0 0 3}$ & Tahun 2004 \\
\hline Arwana & 23.700 & 22.555 \\
Botia & 3.719 .477 & 1.938 .993 \\
Rasbora & 171.330 & 235.690 \\
Gobilis & 5.000 & 47.140 \\
Ringau & 13.022 & 47.850 \\
Pari & 64.457 & 5.746 \\
Gastromyzon & 5.100 & 85.211 \\
Tiger fish & 49.350 & 1.300 \\
\hline
\end{tabular}

Sumber: Karantina Pontianak

Data karantina yang dihimpun dari 18 eksportir pada tahun 2003 adalah sebesar 700.200 ekor meningkat menjadi 950.600 ekor pada tahun 2004. Ekspor ikan hias dari Kalimantan Barat keluar tidak langsung dari Pontianak menuju ke negara tujuan (Singapura, Hongkong, Jepang, Malaysia, dan Uni Eropa) melainkan melalui Jakarta sebagai tempat transit. Sedangkan ikan hias yang tercatat masuk ke Kalimantan Barat adalah jenis koki (125 ekor), arwana Brazil (13.467 ekor), dan Louhan (3.676 ekor) pada tahun 2003. Peningkatan terjadi pada tahun 2004 menjadi 19.022 ekor koki, 24.560 ekor arwana Brazil, dan 1.747 ekor louhan.

\section{KESIMPULAN}

Dari beberapa survai pendahuluan yang telah dilakukan, pada beberapa daerah yang merupakan sentra produksi ikan hias didapatkan bahwa ikan hias air tawar belum mendapatkan perhatian yang cukup untuk pengembangan budidayanya meskipun aktivitas perdagangan ikan hias semakin bertambah. Kegiatan ikan hias air tawar masih didominasi hasil tangkapan dari alam. Untuk jenis ikan yang telah dapat dibudidayakan masih didominasi oleh jenis-jenis yang telah lama dikenal seperti ikan mas koki, cupang, guppy, plati, koi, dan jenis introduksi. Kegiatan budidaya untuk ikan-ikan tersebut terkonsentrasi di kota-kota besar. Sedangkan untuk jenisjenis yang memiliki nilai ekonomis tinggi masih didominasi oleh arwana dan botia. Untuk jenis ikan-ikan konsumsi yang merupakan ikan hias pada waktu masih berukuran kecil seperti Pangasius, belida, dan lain-lain pencarian informasi agak sulit dilakukan karena berdasarkan pengelompokannya seringkali dimasukkan kedalam jenis ikan konsumsi. Untuk melengkapi studi yang sedang dilakukan sangat dibutuhkan kajian survai pada musim yang berbeda mengingat sebagian besar ikan hias air tawar masih mengandalkan hasil tangkapan dari alam yang akan sangat berpengaruh terhadap informasi dan data yang diperoleh.

Domestikasi dan pematangan telur induk yang berasal dari alam telah dapat dilakukan dengan pemberian kombinasi pakan buatan dan cacing. Pada pemeliharaan dan pematangan telur cherax biru, pemberian pakan kombinasi pelet buatan dan cacing dapat memperbaiki produksi benih dibandingkan dengan hanya diberi pelet atau cacing saja. Pemberian cacing pada cherax biru dapat mempercepat masa inkubasi telur.

\section{DAFTAR PUSTAKA}

Anggraeni, M.S., T. Sudarmanto, dan E. Pratiwi. 1994. Perkembangan usaha ikan hias di Provinsi Bali. Bul. Pen. Per. 3: 63- 77.

Anonim. 2005. Komisi Nasional Ikan Hias, Terbentuk. W. Pen. Perik. Indonesia. 24: 15- 16.

Dwiponggo, A. 1993. Ikan hias sebagai komoditas potensial dalam menunjang pengembangan agribisnis perikanan Indonesia. Simposium Perikanan I. Puslitbang Perikanan, Jakarta.

Girsang, M.A., A.N. Hadi, dan A. Wijono. 1994. Perkembangan dan lalu lintas perdagangan ikan-ikan introduksi di Sumatera Utara. Bul. Pen. Per. 3: 4553.

Gustiano, R., Y. Suryanti, dan E. Kusrini. 2005. Perbaikan kualitas dan pengembangan ikan hias air tawar. W. Pen. Perik. Indonesia. 1(2): 59-63

Sastrawidjaja. 2003. Usaha ikan hias di Tulung Agung. W. Pen. Perik. Indonesia. 9: 12-15.

Satyani, D. 2003. Ikan hias air tawar: Prospek dan masalah. W. Pen. Perik. Indonesia. 9: 8-13.

Sukadi, F. 2003. Status dan prospek budidaya ikan hias Indonesia. Makalah disampaikan pada Temu Bisnis Ikan Hias, TMII, Jakarta. 9 pp. 